BAHTERA: Jurnal Pendidikan Bahasa dan Sastra, Volume 19 Nomor 1 Januari 2020

http://journal.unj.ac.id/unj/index.php/bahtera/

P-ISSN : 0853-2710

E-ISSN : 2540-8968

\title{
IMPROVEMENT OF ELEMENTARY SCHOOL STUDENTS' COMPETENCE OF READING COMPREHENSION THROUGH GENERATIVE LEARNING MODEL
}

\author{
Asep Saepurokhman \\ Sekolah Tinggi Keguruan dan Ilmu Pendidikan (STKIP) Sebelas April Sumedang. \\ e-mail: sepdeans3344@gmail.com
}

Accepted: 2020-01-25 , Approved: 2020-01-29 , Published: 2020-01-31

\section{ABSTRACT}

Reading comprehension is a competence that everyone has to possess. It can broaden human's insight in that we will not be left behind as time goes so fast. One of the teachers' efforts as to enhance the reading comprehension competence is to apply a learning model that is able to explore a lot of students' potency. The learning model considered to be capable of developing the students' creative-thinking is a generative model. Based on the result of data analysis, it is known that the process of reading-comprehension learning runs well in full activity of students. The students' tendency to the learning of reading comprehension using such a model is positive in the means of $75.10 \%$. The generative learning model succeeds in enhancing the students' competence of reading comprehension. The means of score before the treatment is only $53.80 \%$, whereas after the treatment it gets $72 \%$ in which the index gain is 0.41 and it is categorized into mediocre. There is difference of reading-comprehension competence between the use of generative learning model and conventional model. It is proven by $t_{\text {-test, }}$ indicating that $t_{\text {-observed }}$ is higher than $t_{\text {-table. }}$ Therefore, the generative learning model is effective and reasonable to use for the teachers in the improvement of stduents' reading-comprehension competence.

Keywords: generative learning model, reading comprehension, learning process, learning outcomes, students' response

\section{INTRODUCTION}

The human resource with high quality, in globalization era, is nowadays absolutely needed. High-qualified human beings are just evoked by the right education. The education can greatly contribute to solve various problems the human beings have. It gets along with Naisbitt in Syaodih (2007) confirming that, "Education and traning must be a major priority, they are the keys to maintaining competitiveness". The quality human resource with tough norms and values, high work-ethos and discipline resulted in the high quality education can overcome various problems faced by human beings. Hence, the education, in accordance with the development of technology and national culture, plays a significant role of

BAHTERA : Jurnal Pendidikan Bahasa dan Sastra, Volume Januari 2020 
BAHTERA: Jurnal Pendidikan Bahasa dan Sastra, Volume 19 Nomor 1 Januari 2020 http://journal.unj.ac.id/unj/index.php/bahtera/

P-ISSN : 0853-2710

E-ISSN : 2540-8968

attaining progression of a country. Such a

One of efforts done for promoting process goes through very long experience.

There are nowadays a lot of critics

to the world of education, especially its

role of forming quality human beings as instructed in the constitution. Rosyada (2009) explains, "the weak human resource resulted in education causes Indonesia indolent to get up from the economic decadence seriously happening in 1998". One of factors causing such a condition is that capability of Indonesia's human resource may not compete with other countries' in international constellation.

Human Development Index (HDI) of Indonesia is so apprehensive since in 1996 Indonesia's HDI got the ranking 102 and continuously declined to 109 in 2000 from 174 countriesin the world, getting one grade over Vietnam and some grades over Myanmar (ranking 125), whereas the other countries of ASEAN have better ranking over Indonesia (Sukmara, 2007).

Indonesian education is shift from centralization to decentralization system in the management of education. In addition, the government's commitment in actualization of quality education can be seen by legalizing the Act of teachers and lecturers in which it contains about improvement of professionalism and teachers' welfare. The government realizes that through the quality education active, creative, innovative, and empowering people can be produced.

Indonesian development is indirectly held by the young generation taking study at several levels of education, either elementary level or high education. They are those people continuing the development of this country. Therefore, the improvement of quality education is properly conducted in sporadic ways to each sector and component, and implemented by all sides taking role of education. It will be hard to acatualize if 
BAHTERA: Jurnal Pendidikan Bahasa dan Sastra, Volume 19 Nomor 1 Januari 2020 http://journal.unj.ac.id/unj/index.php/bahtera/

P-ISSN : 0853-2710

E-ISSN : 2540-8968

we just rely the quality education on the government. It may be just realized in gradual ways and long time, also seeing and giving priority scale, for instance focusing more on quality of the elementary education.

The basic education, mainly elementary schools, is in a strategic position as to enhance quality of Indonesian people. As we know, it makes up a foundation for next education levels. The quality elementary schools will surely constitute a strong base to next education levels, either primary or high education. Th role of basic education is specifically based on the rule of National Education Minister, number 23 in 2006, that the basic education is aimed at constructing foundation of intelligence, knowledge, personality, character-building, and lifeskill to be independent and continuing education to the next levels (Syaodih, 2007). After all, the students need to be provided through a lot of knowledges and

BAHTERA

JURNAL PENDIDIKAN BAHASA DAN SASTRA

suffecient attitude in order to make them capable of living amongst people in high status. Those components can be accomodated through activities of meaningful learning and other ones, for example, an independent activity, reading done by the students continuously.

Reading is one aspect of language proficiencies that needs to be developed. Through the reading activity we can know all thing that we do not know before. Hence, it is understandable that level of students' reading interest may also indirectly play a role of progressing our country. Later on, Rusyana (1984) explains, "The reading competence is very important for maintenance and development of social life, either individually or nationally, in order that the people can survive on earth". It means that the habit and competence of reading constitute may become one of factors causing a country developmental and progressive. 
BAHTERA: Jurnal Pendidikan Bahasa dan Sastra, Volume 19 Nomor 1 Januari 2020 http://journal.unj.ac.id/unj/index.php/bahtera/

P-ISSN : 0853-2710

E-ISSN : 2540-8968

The students as young generation for this country have to possess competence and skill of cultivating information that is increasingly more and more from day to day. Having a high competence of reading, they will not be left behind by the development of both knowledge and technology eventually giving impact to quality of their own life.One of reading competence that they should have is reading comprehension. The students, through such a competence, will totally understand meaning within the textual discourse. The more the students understand a discourse, the broader their thinking-insight is in going along the development of age in all aspect of life.

The reading comprehension is a linguistic activity done by someone in purpose of grasping the meaning contained in the textual discourse deeply, totally, and holistically. This statement is adapted in Soedarso's definition (2006), “Reading comprehension is a competence

BAHTERA JURNAL PENDIDIKAN BAHASA DAN SASTRA inunderstanding of main ideas, supporting sentences (minor details), and overall comprehension". In other words, it is a process done by somebody in the framework of grasping meaning within the reading texts in detail, total, and holistic.

Reading activity is necessary to do for the students in order to get all kinds of knowledge, so that maximal capability may be obtained at the end of learning. People, in other words, may gain a lot of knowledges and skills through empowering the reading activity. The reading proficiency is hence a great catalyst in empowerment of Indonesian human resource, especially the elementary schools' students as young generation continuing the Indonesian development. This case is challenge of teachers, administrators, educational observers in the efforts of seeking out some solution to the improvement of students' reading activity. 
BAHTERA: Jurnal Pendidikan Bahasa dan Sastra, Volume 19 Nomor 1 Januari 2020 http://journal.unj.ac.id/unj/index.php/bahtera/

P-ISSN : 0853-2710

E-ISSN : 2540-8968

Enhancement of the students' reading competence is important to do optimally in any ways. One of the teachers' efforts to help the government's program is to implement a learning model that can explore some various students' potentiality. As a front liner to the world of education, the teachers need to create a learning atmosphere enabling their students to revive cognitive structure and to build up new structures as to accomodate new knowledges.In accordance with such an explanation, laerning is basically a process of developing students' thinking-creativity for the sake of digging up several students' potentials, so that they can compete with others in the global constellation (Firdaus, 2007). One of the models supposed to be capable of developing the students' thinking-creativity is a generative learning.

The generative learning is a model focusing more on actively integrating the new knowledges using knowledge the
BAHTERA

JURNAL PENDIDIKAN BAHASA DAN SASTRA

students have before (Osborne and

Wittrock, 1995). It emphasizes ways of reinforcing human's internal motivation to understand environment by exploring and organizing information, solving problems, and developing language. The point of generative learning is that human brain is not passive receiver of information but active in acceptance of constructing and interpreting input (any information) and make conclusion based on such an input. It involves mental activity in developing of students' thinking-creativity in the line of their learning process. In principle, the generative learning is therefore leaning on views of constructivism by assuming that new knowledge is constructed in students' mind.

The generative learning is considered being suitable for learning reading because both of them employ the mental activity of cultivating information as an input coming from outside. This research is significant to conduct and so 
BAHTERA: Jurnal Pendidikan Bahasa dan Sastra, Volume 19 Nomor 1 Januari 2020 http://journal.unj.ac.id/unj/index.php/bahtera/

P-ISSN : 0853-2710

E-ISSN : 2540-8968

useful for developing knowledges and for solving the reading problems. After all, the writer, in the framework of developing a model of reading learning and of helping the government's model as to enhance the reading interest, is interested in conducting research on application of the generative learning for the students of elementary schools at South Sumedang, Sumedang.

Objectives of this research are to investigate a process of rerading comprehension learning using the generative learning model; to wish to prove that the students' competence of reading comprehension is increasingly better after such a learning model is applied to them; to understandthat there is difference of learning success for the generative learning and the conventional model; and to know response of the grader students of the elementary schools at South Sumedang on process of reading learning using the generative model.

\section{THEORETICAL REVIEW}

\section{Reading Comprehension}

Reading can be defined as a process of thinking, evaluating, imagining, and solving problems. It means that assimilation and accomodation amongst facts, conception, and generalization of something new with the whole psychology of the readers are lasting in the reading procsess. Implicitely it constitues an active process not a passive because the reading is claimed to be capable of interpreting what to read in relying on knowledge or experience they already have around a topic of discourse.

Harris and Hodges (1981) defines that reading is an interaction between readers and writers through a written message at a set of thinking with intention of reading. In other words, it is not only an effort to find out and accept the writer's message, but also to reorganize and process the message through the thinking process of readers. The reading is also a 
BAHTERA: Jurnal Pendidikan Bahasa dan Sastra, Volume 19 Nomor 1 Januari 2020 http://journal.unj.ac.id/unj/index.php/bahtera/

P-ISSN : 0853-2710

E-ISSN : 2540-8968

psycholinguistic process started from the writers'coding and ended by the readers' meaning interpretation.Likewise, there are in this case two processes: first explanation process of the writers' thought in the shape of surface structures and second the readers' reconstruction as to interpret the writers' intention.

Next, Nurhadi (2008:30) defines, "Reading is a process of bridging between something new and something the readers have already known.’'In other words, it can be regarded as an effort of getting information from the written texts through interaction of both the writers and the readers representated by the written forms. In such an interaction there is a contact between characteristics of the readers and those of writers. Their interrelation may evoke two probabilities: success and difficulty in communication between the readers as communican and the writers as communicator. By such an exchange, in order to succesfully communicate with

each other, either the writer or the reader needs to possess competence of both writing and reading.

The explanation above shows that reading definition refers as to comprehension of discourse content. It is reasonable that the readers actively strive for understanding a lot of information conveyed by the writers through the reading texts. In this respect, Kridalaksana (2005) also defines, "Reading is an activity of understanding graphical symbols and their change in the form of silent comprehension". In addition, Tarigan (2005) argues more, "Reading comprehension is to understand simple definition (lexical and grammatical), significance or meaning (purpose and intention), and evaluation (content and form)".

Weiner (1985) states that reading comprehension is a complex process happening to a reader. In such a process, the reader tries to empower all of mental 
BAHTERA: Jurnal Pendidikan Bahasa dan Sastra, Volume 19 Nomor 1 Januari 2020 http://journal.unj.ac.id/unj/index.php/bahtera/

P-ISSN : 0853-2710

E-ISSN : 2540-8968

capacities for the sake of grasping meanings of the reading texts. It is necessary to know that a comprehension may happen if a reader has a means of knowing and understanding words and sentences, and capable of connecting ideas contained in the written forms and knowledge he or she has already. This opinion is in the line of Tampubolon's definition (2000), “ $\quad$ Reading comprehension is a process involving a reasoning and memorization by purpose to find out and understand information communicated by a writer".

Djuanda (2008) explains that in the reading comprehension there are two resources of the needed information: visual and non-visual information.The visual information is obtained from the reading texts, such as words, sentences, paragraphs; whereas the non-visual information is a background of the reader's knowledge relating to what he or she read. Hence, the reading process really coincides with the previous knowledge of readers.It depends not only on information contained within the written texts, but also on a relevant mental structure of the reader as to graspe meaning.

In addition, Smith (1986) also defines that reading ability is a synthesis of elements of comprehension on something and mastery of its meaning and capable of totally grasping main elements of the writer's main ideas and surface structures. Such a definition indicates that the reading ability deals not only with a skill of grasping meaning or main ideas, but with that of understanding style and method of explanation as to reveal up notions as well. So, a skill of reading comprehension is a readiness, ability of analyzing and interpreting graphical symbols, so that it can deeply graspe meaning of the reading texts. The interpretation can begin from meaning of words, sentences, paragraphs to the level of holistic comprehension on a discourse. 
BAHTERA: Jurnal Pendidikan Bahasa dan Sastra, Volume 19 Nomor 1 Januari 2020 http://journal.unj.ac.id/unj/index.php/bahtera/

P-ISSN : 0853-2710

E-ISSN : 2540-8968

\section{Generative Learning Model}

This model, in actuality, is descendant of constructivism theory of learning. This constructivism emphasizes self-invention, new information organization in old norms, and revision of the norms as it is not in effect for a situation (Trianto, 2007). Therefore, students need to give some various problems in order to possess understanding and skill of applying a lot of knowledge, proficiency, and values in the real life.

In the process of -teachinglearning, teachers do not only transfer knowledge to their students, but also should give them chance to develop and construct capacity of knowledge and their ideas by solving some problems and by cooperating with each other to create social and intellectual relationship for their life. One of the most important principles is that the teachers do not only provide konwledge to their students, but have to create a good learning atmosphere as well, 
BAHTERA: Jurnal Pendidikan Bahasa dan Sastra, Volume 19 Nomor 1 Januari 2020 http://journal.unj.ac.id/unj/index.php/bahtera/

P-ISSN : 0853-2710

E-ISSN : 2540-8968

The basic assumption of generative learning model is that knowledge should be constructed within the students' mind. Brain is not a blank slate in which the students passively process and accept new information coming from outside (Osborne dan Wittrock, 1995). This process occures because cognitive conversion is just lasting as conceptions understood by the students before are processed through imbalance in comrehension of the new information. If a hesitation happens to them because of any contradiction between new information and the previous one, in actuality the learning process is going on to them. Hence, in such a learning model the students are claimed to actively construct their knowledges, meanwhile the teachers act as a stimulator, facilitator, and mediator providing a good way for the students' learning. In this matter, Osborne and Wittrock (1995) define that generative learning is a learning model pressing on actively integrating new knowledge to the

previous knowledge students already have before. Thus, each of new knowledge will be examined by operating it to answer several problems or relevant indication to the new knowledge. If the new one gets unccessful in answering the existing problem, it will immediately be saved in a long-term memory of the students.

They, when the teaching-learning process is happening, are active learners not passive receiver of any information or knowledge. The students actively learn about how to construct meaningful understanding of any information they get. In other words, the point of generative learning is that our brain does not passively recieve any infomation but actively construct an interpretation on the information and conclude it. The gnerative learning model really focuses more on an assumption that a learning is in principle a process of developing intellectuals occuring to the learners. Therefore, motivation, attention, beginning concept, 
BAHTERA: Jurnal Pendidikan Bahasa dan Sastra, Volume 19 Nomor 1 Januari 2020 http://journal.unj.ac.id/unj/index.php/bahtera/

P-ISSN : 0853-2710

E-ISSN : 2540-8968

and learning experience need to specially be given priority in implementation of learning using the model. There is an active process done by the students to construct new knowledge based on the previous one they already have possessed in the teaching-learning process.

In this case, Osborne and Witrock (1995) state that generative learning is a model focusing more on ways of reinforcing human's internal impulse to understand environment by exploring and organizing information, perceiving problems and managing to solve them and developing language to express them. It is exact to say that human brain is not really passive receiver of any information but strives for processing and interpreting it based on the previous insight or knowledge he or she already has had. Mental activity of human hence gets involved in the generative learning, especially in thinking process. Thinking is a mental activity of human beings. It will happen if any

stimulus triggers brain to think, for example a problem or information is proposed in the framework of learning. Someone's thinking will surely be developing after doing a learning process, so that his or her knowledge becomes more complex.

A mental activity in the process of generative learning employs function of human memory in the brain. Osborne and Witrock (1995) state that it lasts since a short-term memory connects with a longterm memory in the process of generative learning. The short-term memory is a locus used to take in new information or ideas. Essentially, an individual student always provides a link to for the sake of constructing new knowledge and unifying it at the cognitive structure, so that it can produce a more effective new cognitive structure. In this case, someone's memory will be drastically increasing if he or she just has a part of any information in his or her brain.In the short-term memory an idea 
BAHTERA: Jurnal Pendidikan Bahasa dan Sastra, Volume 19 Nomor 1 Januari 2020 http://journal.unj.ac.id/unj/index.php/bahtera/

P-ISSN : 0853-2710

E-ISSN : 2540-8968

is not only put and saved, but also connected to the long-term memory. The idea, after the connection is operated, is no longer isolated in the short-term memory but come into and saved in the long-term memory, so that it can be used for overcoming a lot of problems or for constructing solution when necessary. After all, the generative learning can function as a way of detecting a thinking pattern, understadning a problem, and solving a particular problem in the process of teaching and learning.

The generative learning model focuses more on scaffolding - a step by a step help in learning and solving a problem (Nur, 2002). A help given to a learner is firstly procedural and structural and next learning responsibility is taken over by the learner. In order words, he or she has to learn for his or her will in order to solve and overcome a problem as he or she has learnt. A teacher hence has to execute his or her function as a facilitator, motivator,

BAHTERA

JURNAL PENDIDIKAN BAHASA DAN SASTRA

and director of learning in that such a learning model can succeed properly.

In addition, Osborne and Witrock (1995) classify the generative learning into four steps: (1) the preliminary step, (2) the focus step, (3) the challenge step, and (4) the application step. The points of them can be seen below:

\section{a. The Preliminary Step}

This first step is also called as an exploration or introductory step. At this stage, a teacher has to guide his or her students to explore knowledge, ideas, beginning conception they have already got before. The beginning conception can be used as a basis or turning point of the learning program that will be conducted. To lead them to do exploration, he or she can give them stimuli, such as questioning, problems, giving assignment relating to conception they will have to learn. The stimuli are given them in order to enhance their motivation and anxiety to those conception they will have to get. 
BAHTERA: Jurnal Pendidikan Bahasa dan Sastra, Volume 19 Nomor 1 Januari 2020 http://journal.unj.ac.id/unj/index.php/bahtera/

P-ISSN : 0853-2710

E-ISSN : 2540-8968

\section{b. The Focus Step}

The second step focuses on new conception the students will have to learn.

They, at this stage, do a lot of activities to prove assumption of a truth or hesitation on a problem dealing with a certain conception. A teacher has to design learning assignments as good as possible in order to give a chance and design them to prove their assumption in their own ways. This explanation is in the line of Wena's statement (2009), that is, "Learning assignments designed by the teachers shouldn't only be a clue or procedural steps, but provide the students an opportunity to work on them in their own ways." In other words, they are given independence to solve some problems or certain tasks correlating with conceptions they learn. At this stage, students' questions come up in terms of new topics or conception they get.

c. The Challenge Step
This third step is also called as

BAHTERA JURNAL PENDIDIKAN BAHASA DAN SASTRA introduction to conception. The students, after finding several things at small groups, decide to make conclusion. They are asked to present their findings in larger discussion group, a class discussion. At this occassion, the teacher give them a chance to share their opinion with each other, so that a student can compare his or her opinion with another one.This sharing idea is surely based on some arguments, findings, facts, and data obtained by them at the previous steps. Therefore, they, at this satge, practice expressing opinion, ideas, critics, and capability of debating based on evidence, facts, or logical reasons.

\section{d. The Application Step}

At this step, it is necessary for the students to manage to solve problems relating to the real world using a new concept they have already got (Wena, 2009:180). Giving question, home assignment, and project-based tasks are 
BAHTERA: Jurnal Pendidikan Bahasa dan Sastra, Volume 19 Nomor 1 Januari 2020 http://journal.unj.ac.id/unj/index.php/bahtera/

P-ISSN : 0853-2710

E-ISSN : 2540-8968

forms of solving problems taken by the teachers at this stage. The given questions begin with the simpler to the most complex one. This way is done in order that the students do not undergo frustration when failing to answer the given questions. They, by working on the simpler questions, have good opportunity to answer them correctly, so that their motivation will be increasingly higher. Giving questions is intended to increase their understanding to the new conceptions they have already learnt. At this stage, the teacher has to guide, lead, and encourage them to solve the problems using the right concepts. So, it is expected that they can overcome the problems, verbally express them in right ways, criticize prblem-solving of another group, assess problem-solving, and make logical conclusion. The new concepts, through such a learning activity, can be constructed and saved in their long-term memory.

\section{RESEARCH METHODS}

The method used in this research is quasi-experiment with the model ofthe matching only pretest-posttest control groupdesign. This method is selected because this research tries to develop a learning model by purpose to see competence of the students' reading comprehension after the process of teaching and learning using the generative model was implemented penelitian ini bersipat uji cobapengembangan suatu model pembelajaran.

The observation, in this research, was conducted twice, namely before and after learning. It was operated on the experimental group given a treatment - the use of generative learning model and the controlling group - the use of conventional learning model. The difference of learning outcomes between the experimental class and the controlling class is assumed to be a result of giving treatment, that is, the generative model. 
BAHTERA: Jurnal Pendidikan Bahasa dan Sastra, Volume 19 Nomor 1 Januari 2020 http://journal.unj.ac.id/unj/index.php/bahtera/

P-ISSN : 0853-2710

E-ISSN : 2540-8968

Subject of this research is all six graders of the state elementary schools at South Sumedang. They are widespreading at the downtown and suburban. The sample-taking technique was conducted by the random sampling. Such a technique is based on an assumption that characteristics of population for each cluster are homogenous. It means that learning environment and facilities are not different at each of the elementary schools.

The main technique used for collecting data of this research is test, questionnaire, and observation. The test was done to measure the students' comprehension on content of the discourse and its form is written and objective multiple-choice test. Each of question has four alternative answers with one correct answer only. The questionnaire was oparated to filter data as the students' responses to the teaching-learning process of reading comprehension using the generative learning model. Through the

BAHTERA JURNAL PENDIDIKAN BAHASA DAN SASTRA given questionnaire the students' tendency to the generative learning model can be detected whether it is negative or positive. Next, the observation was conducted to see and understand the learning process of reading comprehension using such a model. It was operated on the preliminary stage, the focus stage, the evaluating stage in the learning and teaching process.

They, after the data were collected, were analyzed in qualitative and quantitative (using parametric statistics) ways. The qualitative analysis was done in the framework of interpreting meanings on the learning process, competence of reading comprehension, and the tendency of the students' view on the learning they executed. In meanwhile, the quantitative analysis was done by purpose to know what degree of success of reading comprehension learning by using the generative model.

The competence enhancement of students' reading comprehension was 
BAHTERA: Jurnal Pendidikan Bahasa dan Sastra, Volume 19 Nomor 1 Januari 2020 http://journal.unj.ac.id/unj/index.php/bahtera/

P-ISSN : 0853-2710

E-ISSN : 2540-8968

analyzed by comparing the result of pretest with that of posttest. Such an analysis was homegeneity test of two variants, and ttest.

done by using index-gain calculation based on Meltzer's formulae. The calculation was used for knowing the enhancement of students' competence on reading comprehension after the learning process with the generative model was conducted already. The interpretation criterion of index gain used in this research is that if $g$ $>0.70$, the grade gain is then stated in the high category; if the index gainis in the interval $0.30 \leq \mathrm{g} \leq 0.70$, the grade gain is stated in the mediocre category; if $\mathrm{g}<$ 0.30 , the grade gain is stated in the low category. The hypothesis test was done by comparing the result of posttest around learning of reading comprehension between the experimental class and the controlling class through the statistic calculation of two treatments. The hypothesis test was also done by the normality test of distributing the data, the

\section{B. Results and Discussion}

\section{The Learning Process of Reading Comprehension}

Learning of reading comprehension using the generative model generally consists of three parts: pre-learning, the focus, and evaluating. In detail, at this learning activity there are four stages:the preliminary step, the focus step, the challenge step, and the application step as a typical characteristic of the generative learning model use. The writer, in such a learning process, directly took a role as a teacher teaching the learning of reading comprehension using the generative model.This learning activity is conducted by purpose to keep essential things in terms of using the generative model. Three senior teachers, based on the direct observation, had already implemented the 
BAHTERA: Jurnal Pendidikan Bahasa dan Sastra, Volume 19 Nomor 1 Januari 2020 http://journal.unj.ac.id/unj/index.php/bahtera/

P-ISSN : 0853-2710

E-ISSN : 2540-8968

learning stages properly as stated in the course designs the writer made.

The preliminary step is an introductory activity to the learning in the classrooms. Such an activity operated on three sample groups began with conditioning students. This step was done by the researcher to introduce himself and check their attendance. Later on, the researcher explained his intention of conducting the research as well as the basic competence and indicators they should get. After the students were ready for learning, aperception relating to the learning material was implemented by purpose to make them focus more on it. The preliminary step to the three sample groups generally rans well. All student, as this step was done, higly paid attention on each of explanation provided by the researcher, so that it helped success of the learning activity.

At the main activity, as stated above, there are four stages of learning

reading comprehension using the generative model. At the first step (preliminary), the researcher explored the knowledge, ideas, and the beginning concept that the students possess by using question-answer. The learning activity was initiated by doing the question-answer about means of transportation often used by human beings at this time. The material, after a lot of students' ideas on transfortation came up, focused more on on of them, that is, cars. The questionanswer was led to forms, components, and function of cars for the human life.The students' response to the given problems is good. It is proven that the observation result showing that each of elementary schools as the research samples underwent high frequency of question-answer at the beginning of this learning activity.

At the second, the focus step, the students were classified into some small groups. Next, a problem on the component, the form, and the maker of the first car in 
BAHTERA: Jurnal Pendidikan Bahasa dan Sastra, Volume 19 Nomor 1 Januari 2020 http://journal.unj.ac.id/unj/index.php/bahtera/

P-ISSN : 0853-2710

E-ISSN : 2540-8968

the world was given to them, so that every group can seek out a solution to each problem. Based on the observation data, every student of each group practiced the question-answer and the group discussion on the given problems. They strived for identifying and solving the problems by checking and giving priority to the problems considered being important by means of taking benefit of the given resources. The class discussion conducted by them was successful since the researcher directly took a role as a teacher continuously giving guidance and monitoring the learning activity with them.In the world of education there is a principle confirming that the teacher should continuously involve the students to explore and dig up a lot of potentials they have.

Next, the thir step, the challenge, each of student groups was asked to conclude what they have already learnt in the class discussion. Each of groups, after,

BAHTERA JURNAL PENDIDIKAN BAHASA DAN SASTRA

was asked to present their findings in the class discussion. When the discussion was being run, all student was asked to share their ideas with each other reinforced by the logical argument. Such a learning activity to each group ran well. Each delegation of groups expressed his or her opinion as resluted in the discussion of small groups about the components, forms, and the maker of the first car in the world. The teacher, in the learning process, did not correct and blame opinion of each group. Every student freely expressed or constructed his or her new notion, ideas, and knowledge based on the result of discussion. Interaction amongst the classmates in the groups enabled them to develop their social intellegence, for example, expressing opinion or criticizing it politely, and respecting the different ideas among them.

The last step of such a learning activity is application. In this step, the reading text on the related issues were 
BAHTERA: Jurnal Pendidikan Bahasa dan Sastra, Volume 19 Nomor 1 Januari 2020 http://journal.unj.ac.id/unj/index.php/bahtera/

P-ISSN : 0853-2710

E-ISSN : 2540-8968

provided or given to the students. It entitled Benz, Anak Miskin Ciptakan Mobil

Pertama di Dunia taken from the book

Pelajaran Bahasa Indonesia untuk SD/MI

kelas VI, written by Witarsa et al. Each of students was assigned to read it using the silent reading technique The teacher, after the students finished reading it, proposed some questions in terms of the content of the reading text. In the question-answer each of them was given a chance to comment on another student's answer reinforced by the clear argument. Generally each of answers and comment was based on th reading text they read.

At the end of learning activity, every student, in the control of teacher, tried to conclude what material they already had learnt. Next, the written test was given by purpose to measure their competence of reading comprehension after the generative learning was applied in the learning process. In the control of their teacher the implementation of test to each

BAHTERA

JURNAL PENDIDIKAN BAHASA DAN SASTRA

of groups ran well. All student managed to answer every question based on the reading text they read.

Based on the result of data analysis on the learning process of reading comprehension using the generative model, the learning activity ran properly in the students, high activity.In this case, students themselves as active learners strived for solve the given problems in the class discussion, whereas the teacher acted as a facilitator, administrator, and motivator for them. At the beginning step, the teacher can accomodate the students to constructive atmosphere of learning by explaining objectives they have to achieve and by doing aperception to focus on their attention. At the focus step, the learning activity was done by generating the students' motivation and anxiety as stated in the generative learning model. Next, at the last step, the learning evaluation was conducted in order to get comprehensive description on the students' competence of 
BAHTERA: Jurnal Pendidikan Bahasa dan Sastra, Volume 19 Nomor 1 Januari 2020 http://journal.unj.ac.id/unj/index.php/bahtera/

P-ISSN : 0853-2710

E-ISSN : 2540-8968

reading comprehension after finishing the teaching-learning process. All stage is executed as guided in the course guideline. Thus, the generative model, in the framework of enhancing the students' creativity of learning, is one of the learning models that the teachers may select to get success of their teaching.

\section{Enhancing Competence of Reading}

\section{Comprehension}

Based on the result of data analysis the students' competence of reading comprehension is categorized into low before applying the generative model in the learning process. It is proven that the means of score on reading-comprehension competence after giving the treatment to the first experimental class is only $56.3 \%$, to the second $52.5 \%$, and to the third $52.7 \%$. So, the means of scores on the reading-comprehension competence before applying the generative model to all of the samples is $53.8 \%$ and categorized into low score. To know whether or not there is a 
BAHTERA: Jurnal Pendidikan Bahasa dan Sastra, Volume 19 Nomor 1 Januari 2020 http://journal.unj.ac.id/unj/index.php/bahtera/

P-ISSN : 0853-2710

E-ISSN : 2540-8968

competence of reading comprehension after using the generative learning model is increasing and categorized into mediocre. The index gain means of reading-comprehension competence before and after applying the generative learning model to the first experimental class is 0.38 , to the second 0.44 , and to the third 0.40. Thus, the index gainmeans of reading-comprehension competence is 0.41 . It is in the interval $0.30 \leq \mathrm{g} \leq 0.70$. It indicates that their competence after using the generative learning model is in the mediocre category.

\section{Hypothesis Test}

The hypothesis test was conducted by comparing the posttest result of experimental class practicing the generative learning model with the controlling class practicing the conventional learning. It was done using the t-test because based on the previous statistic analysis the three data groups as the research samples have the normal

distribution and homogenous. Based on the result of t-test to the three data groups there is a difference of the learning success between the group using the generative model and the conventional learning. In other words, the proposed hypothesis in this research is accepted.

The explanation above is proven that the result of $t_{\text {-test }}$ calculation to the first experimental group is that $t$-observed equals to 3.08 , whereas $\mathrm{t}_{0.995(52)}$ equals to 2.68 . In fact, in comparation, the t-observed is not in the interval from $-\mathrm{t}_{0.995(52)}$ to $\mathrm{t}_{0.995(52)}$ or 3.08 out of the interval from -2.68 to 2.68 . To the second experimental group, $\mathrm{t}$-observed is 2.75 but $\mathrm{t}_{0.995(50)}$ is 2.68 showing that $\mathrm{t}$ observed is out of the interval from $-t_{0.995(50)}$ to $t_{0.995(50)}$ or 2.75 out of the interval from 2.68 to 2.68. Also, to third experimental group, $\mathrm{t}$-observed is 3.46 but $\mathrm{t}_{0.995(55)}$ is 2.67 indicating that observed is out of the interval from $-t_{0.995(55)}$ to $t_{0.995(55)}$ or 3.46 is out of the interval from -2.67 to 2.67 . Because the $t_{\text {observed }}$ of the third groups is out of the 
BAHTERA: Jurnal Pendidikan Bahasa dan Sastra, Volume 19 Nomor 1 Januari 2020 http://journal.unj.ac.id/unj/index.php/bahtera/

P-ISSN : 0853-2710

E-ISSN : 2540-8968

interval from the $-t_{\text {table }}$ to the $t_{\text {table, }}$ there is

learning. To clarify our understanding of the difference of students' competence on this finding, notice the following table, reading comprehension between using the below: generative model and the conventional

Table 1

The Data of Hypothesis Test Result

\begin{tabular}{|c|c|c|c|c|}
\hline Num & Group & Tobserved & table Interval & Hypothesis \\
\hline 1. & Experiment 1 & 3.08 & -2.68 to 2.68 & accepted \\
2. & Experiment 2 & 2.75 & -2.68 to 2.68 & accepted \\
3. & Experiment 3 & 3.46 & -2.67 to 2.67 & accepted \\
& & & & \\
\hline
\end{tabular}

After the difference of learning success between the experimental group and the controlling one has been proven already, the meansof score on the students' competence of the both groups is compared with each other by purpose to know about which one of the both learning models is better for the reading comprehension.Based on the result of data analysis above, the means of score on the learning result with the use of generative model is higher than the learning result with the use of conventional model to all of the groups. Therefore, it is concluded that the generative learning model is better than the conventional one when it is used for the learning of reading comprehension. In other words, this generative model is successful if used for the learning of reading comprehension to the six-grader students of the elementary schools at South Sumedang. 
BAHTERA: Jurnal Pendidikan Bahasa dan Sastra, Volume 19 Nomor 1 Januari 2020 http://journal.unj.ac.id/unj/index.php/bahtera/

P-ISSN : 0853-2710

E-ISSN : 2540-8968

\section{Students' Response}

Data of the students' perception on the reading-comprehension learning using the generative model is got from the questionnaires. Their answers to the questions can depict whether or not the students' perception on the learning of reading comprehension is positive.

Respondentsgiving response on the learning of reading comprehension with the generative model were taken from the three groups. The number of the first experimental group is 27 students; the second experimental group is 26 students; and the third experimental group is 30 students. All of the respondents is 83 students. Based on the three groups in this research, the most respondents tend to have a positive perception on the learning. This interpretation is proven through the score of their response categorized into fair, positive, very positive getting reach of $88 \%$ or 73 students. The rest is 10 students (12\%) stating the negative and very 
BAHTERA: Jurnal Pendidikan Bahasa dan Sastra, Volume 19 Nomor 1 Januari 2020 http://journal.unj.ac.id/unj/index.php/bahtera/

P-ISSN : 0853-2710

E-ISSN : 2540-8968

material. Although the whole respondents' perception is positive, $67.5 \%$ of the respondents has not had awareness of taking time to read and $59 \%$ of them feels exausted and confused when reading the scientific books.

Thus, it is necessary to encourage the students and make them aware of how important the reading activity is, especially to go against the rapid development of science and technology. All educator is claimed to think about exact ways of how they have high awareness of reading, since by keeping reading in continuous and regular manners they will be able to add vocabulary words and enlarge their thinking-insight. They, by consequence, will not be isolated in this competitive life.Some various synergy efforts as to improve our students' reading interest need to be actualized by all side. They need to think the exact ways of enhancing students' reading interest in high frequency and intensity. Colaboration among

teachers, lecturers, educational, principals, government, students' parents, librarians, and students should be realized to enhance a reader community. The teachers, in other words, are expected to construct good literacy, so that the students have awareness, will, attention, and motivation to read. All side should go hand in hand to develop interest, habit, and capability of reading. Eventually they will be smart generation and be able to be the best leaders to this country.

\section{CONCLUSION AND SUGGESTION}

The generative learning is one of learning models that the teachers can select in the process of learning and teaching. It is important for them to conduct. The model can enhance activity, creativity, and thinking of students to solve the problem relating to the new concept they have to learn. The students' competence of reading comprehension, through a series of learning activity focusing more on integration of the new concept to the

BAHTERA : Jurnal Pendidikan Bahasa dan Sastra, Volume Januari 2020 
BAHTERA: Jurnal Pendidikan Bahasa dan Sastra, Volume 19 Nomor 1 Januari 2020 http://journal.unj.ac.id/unj/index.php/bahtera/

P-ISSN : 0853-2710

E-ISSN : 2540-8968

concept the students already have before, is significantly increasing. When the learning-teaching process happens, the students are not passive receivers of various knowledge but active and work to construct the meaningful understanding of any information they get based on the knowledge they have already had.

A teacher, if he or she will apply the generative learning model for the reading learning, has to possess a skill of good questioning to arrouse his or her students' thinking-creativity of solving

\section{REFERENCES}

Arends, R. (1997). Classroom Instructional Management. New York: The McGraw Hill Company.

Bond, G.L. et al. (2003). Reading Difficulties. Englewood Cliffs, New Jersey : Prince Hall, Inc. 
BAHTERA: Jurnal Pendidikan Bahasa dan Sastra, Volume 19 Nomor 1 Januari 2020 http://journal.unj.ac.id/unj/index.php/bahtera/

P-ISSN : 0853-2710

E-ISSN : 2540-8968

Damaianti, V. S. (2001). Strategi Volisional

Melalui Dramatisasi dalam Bidang

Pendidikan Membaca. Ringkasan

Disertasi Promosi Doktor UPI

Bandung. Bandung: Tidak diterbitkan.

Djuanda, D. (2008). Pembelajaran

Keterampilan Berbahasa Indonesia di

Sekolah Dasar. Bandung: Pustaka

Latifah.

Firdaus. (2007). Pembelajaran Terkini

Perpaduan Indonesia Malaysia.

Yogyakarta: Pustaka Pelajar.

Harris, TL. \& Hodges, E.R. (1981). A Dictionary of Reading and Related

Terms. Washington : International

Reading Association.

Hatch, E. \& Farhady, H. (2002). Research Designs and Statisicts for Applied Linguisticts. New York: McGrawHill, inc. 
BAHTERA: Jurnal Pendidikan Bahasa dan Sastra, Volume 19 Nomor 1 Januari 2020 http://journal.unj.ac.id/unj/index.php/bahtera/

P-ISSN : 0853-2710

E-ISSN : 2540-8968

Holil, A. (2008). Pembelajaran Generatif.

[Online]. Tersedia: http//anwarholil.

blogspot.com. [2 Januari 2012].

Joyce, B. \& Weill, M. (2009). Models of

Teaching. New Jersey: Pearson

Education, Inc.

Meltzer, D.E. (2002). The Relationship between Matematics Preparation and

Conceptual Learning Gain in

Physics: A Possible "Hidden

Variable" in Diagnostics Pretest

Scores. American Journal of Physics.

[Online]. Tersedia:

http://www.physics.iastate.edu/per/do

cs/AJP-Des-2002-Vo.70-1259-

1268.pdf [Agustus 2012].

Nur, M. (2002). Psikologi Pendidikan, Fondasi

untuk Pengajaran. Surabaya: PSMS

Program Pascasarjana Unesa. 
BAHTERA: Jurnal Pendidikan Bahasa dan Sastra, Volume 19 Nomor 1 Januari 2020 http://journal.unj.ac.id/unj/index.php/bahtera/

P-ISSN : 0853-2710

E-ISSN : 2540-8968

Osborne, R. J., \& Wittrock, M.C. (1995).

Learning science: A generative

approach. Science Education.

California: Wiley Periodicals, Inc.

Redway, K. (1998). Rapid Reading. London :

Pan Books, Ltd.

Rosyada, D. (2007). Paradigma Pendidikan

Demokratis, Sebuah Model Pelibatan

Masyarakat dalam Penyelenggaran

Pendidikan. Jakarta: Kencana Prenada

Media Group.

Soedarso. (2006). Sistem Membaca Cepat dan

Efektif. Jakarta : Gramedia.

Sukmara, D. (2007). Implementasi Life Skill

dalam KTSP melalui Model

Manajemen Potensial Qodrati.

Bandung: Mughni Sejahtera.

Syaodih, E. (2007). Pengembangan Model

Pembelajaran Kooperatif untuk

BAHTERA : Jurnal Pendidikan Bahasa dan Sastra, Volume Januari 2020 
BAHTERA: Jurnal Pendidikan Bahasa dan Sastra, Volume 19 Nomor 1 Januari 2020 http://journal.unj.ac.id/unj/index.php/bahtera/ P-ISSN : 0853-2710

E-ISSN : 2540-8968

Meningkatkan Keterampilan Sosial.

Ringkasan Disertasi Promosi Doktor

UPI Bandung. Bandung: Tidak

diterbitkan.

Tampubolon, D.P. (2000). Kemampuan

Membaca, Teknik Membaca Efektif

dan Efisien. Bandung : Angkasa.

Trianto. (2007). Model-model Pembelajaran

Inovatif Berorientasi Konstruktivistik.

Jakarta: Prestasi Pustaka Publisher.

Weiner, H.S. (1985). Reading Skill Hand Book.

USA : Houghton Mifflin and Co.

Wena, M. (2009). Strategi Pembelajaran

Inovatif Konteporer, Suatu Tinjauan

Konseptual Operasonal. Jakarta:

Bumi aksara. 